R.W.F. de Bruin

E. Heineman

R. L. Marquet

\section{Small bowel transplantation: an overview}

Received: 10 November 1992

Received after revision: 25 February 1993

Accepted: 30 March 1993

R.W.F. de Bruin ( $)$ R. L. Marquet Department of General Surgery, Erasmus University, P. O. Box 1738 , NL-3000 DR Rotterdam, The Netherlands

E. Heineman

Department of General Surgery, University of Maastricht, P. Debyelaan 25 NL-6202 AZ Maastricht, The Netherlands

\begin{abstract}
Small bowel transplantation (SBT) would, in theory, be the treatment of choice for patients suffering from the short bowel syndrome. Although SBT has been done with a considerable degree of success in some centers [36, 145], it is by no means an established or widely applicable therapy for those with short bowel syndrome. The small bowel is unique among vascularized organ grafts because it not only elicits a vigorous rejection reaction but is also capable of inducing graft-versus-host disease (GVHD). Rejection of the
\end{abstract}

graft does not only lead to loss of function but also to bacterial translocation. The risk of fatal sepsis is aggravated by the immunosuppression given to prevent rejection. Here, the history of SBT is described, and recent developments in experimental and clinical SBT, as well as future prospects for this theoretically optimal treatment modality for patients dependent on total parenteral nutrition (TPN) for life, are outlined.

Key words Small bowel transplantation

\section{History}

In 1959, Lillehei et al. [73] described, for the first time, a technique for orthotopic small bowel transplantation (SBT) in the dog. Many experimental studies followed and several patients received a small bowel transplant. However, the initial enthusiasm for SBT waned when it became evident that rejection and sepsis were recurrent problems that could not easily be solved and when total parenteral nutrition (TPN) was introduced as satisfactory therapy for otherwise untreatable patients. With the introduction of the potent immunosuppressive agent cyclosporin $\mathrm{A}$ ( $\mathrm{CyA}$ ) came a renewed interest in SBT, which is presently on the verge of becoming an established procedure in transplant medicine.

\section{Experimental models of small bowel transplantation}

A number of models are used to study SBT, each having its own advantages and disadvantages. Monchik and Russell [90] first used parent and F1 hybrid rats in SB'T. By using rats from two inbred parent $(\mathrm{P})$ strains and their offspring (F1), they were able to distinguish graft-versus-host disease (GVHD) from rejection. Transplantation from $P$ to F1 produces only GVHD, whereas in the reverse siutation only rejection occurs. The relevance of these one-way semiallogeneic models to the clinical situation, in which both GVHD and rejection may occur, is uncertain [114] and, hence, fully allogeneic combinations, in which the graft is transplanted from $\mathrm{P} 1$ to $\mathrm{P} 2$, are used to study the possible interaction between GVHD and rejection. Syngeneic transplantation from $\mathrm{P} 1$ to $\mathrm{P} 1$ can be used to study the effects of ischemia and lymphatic and neural disruption while the immunologically induced traumas are circumvented (Table 1). In large animals, syngeneic transplantation finds its equal in autotransplantation, in which the arterial and venous blood supply are divided and reanastomosed, the lymphatics and nerves are disrupted, and the bowel is cut and reanastomosed [73,84, 107].

With respect to the position of the bowel, two models are used. In one, the bowel is placed heterotopically; the recipient small bowel remains in situ, and the graft is placed as a Thiry-Vella fistula with both ends of the graft anasto- 
Table 1 Immunological reactions after small bowel transplantation

\begin{tabular}{lll}
\hline Model & GVHD & Rejection \\
\hline $\mathrm{P} 1 \rightarrow \mathrm{P} 1$ & - & - \\
$\mathrm{F} 1 \rightarrow \mathrm{P}$ & - & + \\
$\mathrm{P} \rightarrow \mathrm{F} 1$ & + & - \\
$\mathrm{P} 1 \rightarrow \mathrm{P} 2$ & + & + \\
\hline
\end{tabular}

mosed as stomas in the abdominal wall of the recipient. The oral end of the graft may also be ligated or placed as a duodenostoma, whereas the distal end is anastomosed end-to-side to the terminal ileum of the recipient bowel.

In the orthotopic model, the recipient small bowel is resected and the graft is placed in continuity with the remaining duodenum and terminal ileum of the recipient. In this model, recipient survival is dependent upon the functioning of the graft. Although orthotopic SBT (OSBT) may be the preferred model $[38,68]$, the reported longer operative time and higher incidence of complications [62, $63]$ have resulted in a number of studies in which heterotopic SBT (HSBT) has been used [150]. In skilled hands, however, the operative time and technical success rate for both techniques are not significantly different [159]. Results obtained after HSBT and OSBT are not comparable $[38,68]$. After HSBT, rejection of the graft is defined as the development of a palpable abdominal mass and necrosis of stomas $[38,68]$. However, the graft may become encapsulated and fibrotic rather than necrotic and perforated, and the recipient may survive despite the graft loss, which makes the end point of rejection more difficult to define $[38,123]$. Moreover, probably due to a lack of intraluminal nutrients, atrophy of the mucosa occurs [151], and the permeability of these grafts 7 days postoperatively is significantly higher than after OSBT. Graft survival after HSBT can be prolonged more easily than after OSBT [38]. In conclusion, OSBT may be the preferred model for both immunological and functional studies.

Venous drainage of the graft may be in the portal or in the systemic circulation. Although technically more demanding [131], portoportal drainage is the more physiological route. Beneficial effects of this route on graft survival have been reported $[63,123]$, although they may be of minor importance [69]. Portocaval shunting may cause metabolic complications, such as a rise in blood ammonia levels, and liver atrophy. The effects of portocaval shunting after SBT appear to be minor, and either type of venous drainage may be used safely $[53,63,123,131]$.

Lillehei et al. [73] were the first to describe a technique for functional bowel transplantation in the dog. After the bowel had been removed, it was autotransplanted and subsequently had good function. Different models of heterotopic and orthotopic placement of the bowel, with either systemic or portal venous drainage, are used as preclinical models for the immunological and functional studies. Since pigs are inexpensive, easily cared for, and gain weight rapidly, they are also used in SBT $[35,54,106]$.

\section{Histology}

The sequence of histological changes after SBT is well defined, although there may be slight differences, depending on the model studied $[46,76,90,120]$.

In our BN-to-WAG fully allogeneic, orthotopic total SBT model, early intestinal lesions on days 4-6 post-transplantation were characterized by mild infiltration of the lamina propria and submucosa by mononuclear cells and neutrophils and by mild multifocal death of cryptepithelial cells. The number of mononuclear cells increased to moderate over a period of a few days, while only a few neutrophils were seen after 6 days. Crypt cell death was also observed on days 7-12 post-transplantation, but it never became a prominent feature. Fibrin thrombi in mucosal capillaries were observed with increasing frequency during the course of graft rejection. This was associated with extensive necrosis of the mucosa at 11 and 12 days after grafting. Widespread thrombosis, resulting in ischemia, is probably the principal cause of graft necrosis. Mononuclear cells accumulated around blood vessels in the mesentery. At 11-12 days post-transplantation, early changes in the arteries included endothelial hypertrophy, and this was followed by mild intimal proliferation and thrombosis.

The mesenteric lymph node became rapidly depleted of lymphocytes, which were replaced by large mononuclear cells, presumably macrophages, and increasing numbers of fibroblasts.

Immunohistochemical changes generally predate histological ones. In rats, a huge number of macrophages are seen infiltrating the submucosa, peaking on day 7 . Increasing numbers of $T$ cells are seen starting on day 3 in the submucosa, whereas their numbers are increased in the crypts on days 5 and 7 [44]. In humans, increased number of macrophages and CD $4^{+}$cells are found in the lamina propria, and crypts express HLA-DR antigens [49]. Others have found pericryptic infiltrates of $\mathrm{CD} 3^{+}$cells and HLA-DR expression on crypt enterocytes 3-5 days before histological changes became apparent [6]

\section{Immunosuppression with cyclosporin}

Before $\mathrm{Cy} A$ became available, other immunosuppressive agents were used in attempts to prolong small bowel allograft survival. Taylor et al. [141] used high doses of azathioprine in the artificial model of transplantation of a small segment of small bowel as a Thiry-Vella fistula in the neck of dogs. Only marginal prolongation of graft survival was found. Preston et al. [104], using the same model, added prednisone to azathioprine and found prolongation of graft survival from 9 to 27.5 days. Addition of antilymphocyte serum (ALS) to this regimen prolonged graft survival to a mean of 38 days [41].

Interest in SBT has been rekindled since the introduction of the potent immunosuppressant CyA [57]. Reznick 
Table 2 Use of FK 506 in rat small bowel transplantation. OSBT, Orthotopic small bowel transplantation; HSBT, heterotopic small bowel transplantation; $p c$, portocaval venous drainage; $\mathrm{pp}$, portoportal venous drainage; $\mathrm{nr}$, not reported

\begin{tabular}{|c|c|c|c|c|c|}
\hline Author & Model $^{\alpha}$ & $\begin{array}{l}\text { FK } 506 \text { dose } \\
(\mathrm{mg} / \mathrm{kg})\end{array}$ & $\begin{array}{l}\text { Additonal treatment/ } \\
\text { remarks }\end{array}$ & Survival $^{\mathrm{b}}$ (days) & GVHD \\
\hline Hoffmann et al. [45] & HSBT-pc & $\begin{array}{l}2 \mathrm{mg} / \mathrm{kg} \text {, days } 3-6 \\
2 \mathrm{mg} / \mathrm{kg} \text {, days } 3-6+ \\
1 \mathrm{mg} / \mathrm{kg} \text {, days } 8-30, \text { qod } \\
1 \mathrm{mg} / \mathrm{kg} \text {, days } 8-30, \text { qod } \\
1 \mathrm{mg} / \mathrm{kg} \text {, days } 8-30, \text { qod }\end{array}$ & $\begin{array}{l}\text { One-way rejection } \\
\text { One-way GVHD }\end{array}$ & $\begin{array}{r}34.9 \pm 30.8 \\
50.6 \pm 46.5 \\
\\
83.0 \pm 82.6 \\
188.0 \pm 72.1\end{array}$ & $\begin{array}{l}\text { None } \\
\text { None } \\
\text { None } \\
12.5 \%\end{array}$ \\
\hline Lee et al. [70] & OSBT & $2 \mathrm{mg} / \mathrm{kg}$, days $0-4$ & & $>180$ & None \\
\hline de Bruin et al. [10] & OSBT-pc & $\begin{array}{l}2 \mathrm{mg} / \mathrm{kg} \text {, days } 0,1,2,4,6 \\
2 \mathrm{mg} / \mathrm{kg} \text {, days } 0,1,2,4,6\end{array}$ & 5 Gy donorirr & $\begin{array}{l}28.5 \pm 6.8 \mathrm{SE} \\
31.1 \pm 5.7 \mathrm{SE}\end{array}$ & $\begin{array}{l}\text { Severe } \\
\text { None }\end{array}$ \\
\hline Fukuzawa et al. [32] & HSBT-pc & $\begin{array}{l}0.3 \mathrm{mg} / \mathrm{kg} \text {, days } 0-14 \\
0.3 \mathrm{mg} / \mathrm{kg} \text {, days } 0-14\end{array}$ & $\begin{array}{l}1.0 \mathrm{mg} / \mathrm{kg} \\
\text { days }-8-4 \\
1.0 \mathrm{mg} / \mathrm{kg} \\
\text { days }-8--4 \\
+ \text { DST, day }-8^{\mathrm{c}}\end{array}$ & $\begin{array}{c}9.8 \pm 2.8 \\
62.2 \pm 33.6\end{array}$ & $\begin{array}{l}\mathrm{nr} \\
\mathrm{nr}\end{array}$ \\
\hline Murase et al. [94] & OSBT-pp & $\begin{array}{l}0.15 \mathrm{mg} / \mathrm{kg} \text {, days } 0-13 \\
0.15 \mathrm{mg} / \mathrm{kg} \text {, days } 0-13\end{array}$ & & $\begin{array}{l}44.5 \text { median } \\
\text { "20-30 days" }\end{array}$ & $\begin{array}{l}\text { Mild, self-limiting } \\
\text { Severe }\end{array}$ \\
\hline Murase et al. [93] & OSBT-pc & $0.64 \mathrm{mg} / \mathrm{kg}$, days $0-13$ & & 121 , median & None \\
\hline Santiago et al. [116] & HSBT-pc & $\begin{array}{l}0.3 \mathrm{mg} / \mathrm{kg} \text {, days } 0-13 \\
1.0 \mathrm{mg} / \mathrm{kg} \text {, days } 0-13 \\
2.0 \mathrm{mg} / \mathrm{kg} \text {, days } 0-13 \\
0.3 \mathrm{mg} / \mathrm{kg} \text {, days } 0-13 \\
\text { None }\end{array}$ & $\begin{array}{l}\text { donor } 2 \mathrm{mg} / \mathrm{kg} \mathrm{FK} \text {, } \\
\text { days }-3,-2,-1 \\
\text { donor } 2 \mathrm{mg} / \mathrm{kg} \mathrm{FK} \text {, } \\
\text { days }-3,-2,-1\end{array}$ & $\begin{array}{r}6.8 \pm 0.8 \\
12.4 \pm 8.4 \\
17.4 \pm 4.7 \\
41.2 \pm 3.8 \\
12.2 \pm 1.9\end{array}$ & $\begin{array}{l}\mathrm{nr} \\
\mathrm{nr} \\
\mathrm{nr} \\
\mathrm{nr}\end{array}$ \\
\hline Tadeka et al. [140] & HSBT & $\begin{array}{l}0.32 \mathrm{mg} / \mathrm{kg} \text {, days } 0-13 \\
0.32 \mathrm{mg} / \mathrm{kg} \text {, days } 0-13\end{array}$ & $\begin{array}{l}\text { minor } \mathrm{HC} \text { incom- } \\
\text { patible } \\
\text { major } \mathrm{HC} \text { incom- } \\
\text { patible }\end{array}$ & $\begin{array}{l}80 \%>175 \\
38.0 \pm 6.3\end{array}$ & $\begin{array}{l}\mathrm{nr} \\
\mathrm{nr}\end{array}$ \\
\hline Hatazawa et al. [42] & OSBT & $\begin{array}{l}1.0 \mathrm{mg} / \mathrm{kg} \text { per day, } \\
8 \text { weeks, s. c. }\end{array}$ & & $">8$ weeks" & None \\
\hline Stangl et al. [136] & $\mathrm{nr}$ & $\begin{array}{l}10 \mathrm{mg} / \mathrm{kg} \text { CyA, days } 0-5 \\
10 \mathrm{mg} / \mathrm{kg} \text { CyA, days } 0-5\end{array}$ & $\begin{array}{l}\text { FK } 506,2 \mathrm{mg} / \mathrm{kg} \text {, } \\
\text { days } 13-15\end{array}$ & $\begin{array}{l}27.3 \pm 4.8 \\
>270\end{array}$ & None \\
\hline Utsunomiya et al. [147] & OSBT-pc & $\begin{array}{l}0.1 \mathrm{mg} / \mathrm{kg} \text {, days } 0-29 \\
0.3 \mathrm{mg} / \mathrm{kg} \text {, days } 0-29 \\
0.5 \mathrm{mg} / \mathrm{kg} \text {, days } 0-29\end{array}$ & & $\begin{array}{l}13.4 \pm 3.07 \\
34.6 \pm 12.79 \\
32.6 \pm 26.16\end{array}$ & $\begin{array}{l}\mathrm{nr} \\
\mathrm{nr} \\
\mathrm{nr}\end{array}$ \\
\hline Yamataka et al. [158] & $\mathrm{nr}$ & $\begin{array}{l}1.0 \mathrm{mg} / \mathrm{kg} \text {, days } 3-5, \text { i.p. } \\
1.0 \mathrm{mg} / \mathrm{kg} \text {, days } 3-5, \mathrm{i} . \mathrm{p} . \\
+\alpha-\mathrm{ICAM}-1,1 \mathrm{mg} / \mathrm{kg}, \mathrm{da}\end{array}$ & & $\begin{array}{l}">20 " \\
">20 "\end{array}$ & $\begin{array}{l}\mathrm{nr} \\
\mathrm{nr}\end{array}$ \\
\hline
\end{tabular}

${ }^{a}$ Fully allogeneic model, unless otherwise stated. FK was administered intramuscularly, unless otherwise stated

${ }^{b}$ Mean survival in days, unless otherwise indicated ${ }^{\mathrm{c}}$ DST + donor-specific blood transfusion
$\mathrm{d}^{\mathrm{M}}$ Murase et al. 1991: mild, self-limiting GVHD in BN-to-Lew com-
bination, severe GVHD in Lew-to-BN combination

combination used. We have shown that in the BN-toWAG rat donor-host combination, long-term allograft survival is easy to achieve using short courses of CyA, whereas in the reverse WAG-to-BN model, CyA has only a limited efficacy in prolonging graft survival [9]. In unidirectional P-to-F1 hybrid models, CyA appears to be less effective in preventing GVHD [58].

In large animal models, prolongation of graft survival is hard to achieve, but continuous intravenous (i.v.) infusion of CyA has been shown to result in long-term allo-
CyA is able to significantly prolong small bowel allograf survival [122]. This is highly dependent upon the rat strain et al. [108] first reported prolongation of graft survival to tion of $25 \mathrm{mg} / \mathrm{kg}$ per day. Many dogs died of pneumonia perhaps due to the malnutrition caused by chronic rejecaging results in both dogs and pigs have also been reported by others [105].

In both unidirectional and fully allogeneic rat models, 
graft survival (122 \pm 33 days) in pigs, without any animals dying from rejection [34]. These results were achieved with $15 \mathrm{mg} / \mathrm{kg}$ CyA given i.v. for 7-10 days, followed by $30 \mathrm{mg} / \mathrm{kg}$ per day orally, tapered to $15 \mathrm{mg} / \mathrm{kg}$ over $3-4$ months. However, high CyA blood levels of approximately $600-700 \mathrm{ng} / \mathrm{ml}$ were measured that could lead to toxicity in the kidney [28] and bowel [19] and to an unacceptably high risk of developing malignancies [100]. Recently, it was reported that MHC matching prolonged survival of segmental ileal grafts in nonimmunosuppressed beagle dogs [43] and that graft rejection can be prevented with $\mathrm{CyA}$ when donor and recipient are fully MHC-matched: CyA dosages in this group were $15 \mathrm{mg} /$ $\mathrm{kg}$ i.m. from 1 day before surgery until the end of the $1 \mathrm{st}$ postoperative week and $30 \mathrm{mg} / \mathrm{kg}$ per day orally until day 200 post-transplantation. Recipients of an MHCmatched graft survived for a mean of 211 days without signs of rejection during CyA therapy. MHC-mismatched dogs survived for a mean of 113 days with four of six animals showing rejection that occurred during CyA treatment [88].

Pretransplant CyA treatment (pretreatment) of the recipient is associated with a reduced incidence of acute rejection in kidney transplantation [47]. Moreover, Kahan et al. [51] and Rogerson et al. [110] found that low plasma CyA levels in the early postoperative period are associated with a higher incidence of rejection following human renal transplantation. However, in an experimental rat study we were unable to significantly prolong small bowel allograft survival after preloading the recipient with highdose CyA, as compared to postoperative immunosuppression only, although no acute rejection occurred (unpublished data). It is generally thought that oral administration of CyA should be avoided [57] since the disrupted lymphatics of the graft are unable to transport this lipophilic drug to the blood. Although we have shown that absorption of orally administered CyA after total small bowel resection is severely impaired [11], we found no lowered plasma trough levels in the 1st week post-transplantation. This finding is consistent with observations by Aeder et al. [1] and LaRosa et al. [64], who found that oral and intraluminal CyA absorption within 1 week after transplantation did not differ significantly from preoperative or control values. This indicates that there must be an alternative mechanism by which $\mathrm{CyA}$ is delivered to the blood. By administering CyA intraperitoneally to normal dogs, Cohen et al. [17] have shown that some absorption may take place via the peritoneum. It is possible that after transplantation CyA in the lymph leaks into the peritoneal cavity through the disrupted lymphatics and is subsequently reabsorbed. Thus, even before lymph vessel continuity is re-established 4-10 weeks post-transplantation, as is shown to happen in different models $[61,113$, 121], orally administered CyA is absorbed. It has, however, been shown that CyA absorption is highly variable and unpredictable during the early postoperative period and, moreover, that rejection can impair the ability of the graft to absorb CyA [17]. Therefore, it seems justified to advocate parenteral administration as the main route, especially in the first months after transplantation. Whether concomitant oral treatment can be of benefit due to local immunosuppressive effects needs to be investigated.

\section{Other forms of immunosuppression}

FK 506 and rapamycin (RAPA) are both macrolides produced by Streptomyces species with potent immunosuppressive activity [14]. FK 506, like CyA, counteracts mitogenic or antigenic stimulation at an early stage of T-cell activation, whereas RAPA intervenes in events more closely related to DNA synthesis. All three drugs exert their action via a class of binding proteins known as immunophilins, which possess cis-trans peptidyl prolyl isomerase activity. There is evidence that FK 506 and RAPA bind to the same binding site, whereas CyA binds to the similar, but nonidentical, cyclophilin. Probably as a result of this, RAPA has been shown to antagonize the FK 506-induced inhibition of T-cell proliferation, and FK 506 has been shown to antagonize the action of RAPA, although potentiation of either drug may be achieved using equimolar concentrations of the two agents. Combinations of CyA and FK 506 or RAPA invariably result in a greater inhibition of mitogen and alloantigen-induced T-cell responses.

RAPA suppresses a wider spectrum of $\mathrm{T}$ - and B-cell activation pathways than FK 506 or CyA. Interest in these two agents for use in SBT is a direct result of the potency of RAPA and FK 506 in prolonging graft survival [144].

\section{FK 506}

Hoffman et al. [45] performed an extensive study on the use of FK 506 for SBT in rats (Table 2). They showed that long courses of FK 506 are more effective than $\mathrm{CyA}$ in the prevention of acute rejection and lethal GVHD in semiallogeneic models. Short courses of $2 \mathrm{mg} / \mathrm{kg}$ on days $0-6$ post-transplantation prevented rejection in the fully allogeneic ACI-to-Lew model. In the model used, a 20 times higher dose of CyA was needed to obtain comparable survival times. No clinical GVHD was observed. Using the BN-to-Lew rat model, Lee et al. [70] found similar results, while Stangl et al. [136] showed in the same model that FK 506 is able to reverse an ongoing chronic rejection process. We were unable to find superior immunosuppressive effects of short-course FK 506 over CyA using the fully allogeneic WAG-to-BN rat strain combination [10]. Moreover, after FK 506 treatment, severe GVHD was seen. This was also observed by Murase et al. [94] in the BN-to-Lew combination giving $0.15 \mathrm{mg} / \mathrm{kg}$ for 14 days. Hatazawa et al. [42], on the other hand, observed 
prolonged survival after administration of $1 \mathrm{mg} / \mathrm{kg}$ per day for 8 weeks in the same model.

Masutani et al. [82] found in a P-to-F1 hybrid model that 14 days after HSBT using $0.32 \mathrm{mg} / \mathrm{kg}$ per day, FK 506 animals showed no histological signs of GVHD, and Markus et al. [79] showed that FK 506 is able to reverse ongoing GVHD after bone marrow transplantation better than CyA and RAPA.

\section{Rapamycin}

Continuous i.v. administration of $0.80 \mathrm{mg} / \mathrm{kg}$ of RAPA for 14 days was shown to significantly prolong allograft survival [138]. Using Lew and (LBN) F1 hybrid one-way models, it was shown that RAPA is able to suppress both isolated rejection and GVHD, although its effect on GVHD is less potent than on rejection [52]. Chen et al. [15], however, found RAPA to be equipotent in suppressing isolated rejection and GVHD in the same model. They also showed that RAPA is synergistically effective with CyA. Similar immunosuppressive efficacy as with CyA was achieved with a five times lower dose of RAPA after fully allogeneic rat SBT [138]. No toxicity was reported in these studies.

Both FK 506 and RAPA may prove to be the more potent, less toxic immunosuppressants needed for successful clinical SBT, but this has yet to be evaluated clinically.

\section{Immunomodulation}

It has been widely recognized that preconditioning of the recipient with donor-specific blood transfusions (DST) may lead to prolongation of allograft survival in both experimental [80] and clinical [97] transplantation. In the BN-to-WAG rat donor-host combination, DST are very effective in prolonging heart and kidney graft survival [80]. However, three pretransplant DST had no effect on total or segmental SBT in this model. When DST was combined with low-dose CyA administration, no additional prolongation of graft survival could be measured [8]. Similar results were reported by Fecteau et al. [30]. In contrast, Martinelli et al. [81] did find a synergistic effect of CyA and DST, and with FK 506, DST acts synergistically as well [32].

These findings indicate that DST may contribute to the prevention of rejection, but more studies are needed to determine whether DST can be a therapeutic option in living related SBT.

Ultraviolet B (UV-B) irradiation of transfused cells intensifies the effects of DST in rat transplantation models. UV-B-irradiated leukocyte transfusions in combination with short-term, low-dose CyA immunosuppression is significantly efficacious in prolonging small bowel allograft survival. The mechanism includes, at least in part, a component of donor-specific unresponsiveness [157].

\section{Graft-versus-host disease after small bowel transplantation}

Monchik and Russel [90] first showed that transplantation of the small bowel may produce a lethal GVHD in Pto-F1 hybrid rat models. This GVHD shows histological similarities to that induced by bone marrow transplantation [92] and is caused by $\mathrm{T}$ lymphocytes originating from the transplanted gut and its mesenteric lymph nodes [58, 149]. Clinically, it is characterized by dermatitis, alopecia, a hunched posture and, eventually, death of the animal. Observations in unidirectional GVHD or rejection models are of uncertain relevance to the clinical situation, in which a two-way reaction between rejection and GVHD may occur [57]. In fully allogeneic SBT, rejection rather than GVHD seems to predominate $[31,69,90]$. In some fully allogeneic models, $30 \%-50 \%$ of the animals show clinically overt GVHD, distinguished from that in the one-way model by its nonlethal, short-lived nature. Little is known about the interaction between rejection and GVHD in these models. Cohen et al. [16] investigated the effect of graft irradiation with 0.5 and $1.5 \mathrm{~Gy}$ prior to transplantation in a canine small bowel allograft model. They found that pretreatment with $1.5 \mathrm{~Gy}$ leads to rejection of the small bowel allografts in 9.2 days. Pretreatment with $0.5 \mathrm{~Gy}$, however, prolonged graft survival to a mean of 28 days. Therefore, they hypothesized that there is a balance between rejection and GVHD, and that the development of subclinical GVHD after 0.5 Gy irradiation results in prolonged graft survival.

Since the early 1960 s it has been known that GVHD depresses the host's immunological reactivity [48]. This is best shown by clinical results obtained with T-cell-depleted bone marrow transplantation. On the one hand, T-cell depletion significantly reduces acute GVHD; on the other hand, it substantially increases graft rejection [137]. GVHD is also known to be immunosuppressive after experimental spleen, cell, and small bowel transplantation [35].

Histopathologically, GVHD is characterized by a loss of the normal architecture of the spleen, lymph nodes, and thymus $[22,35,124]$. This leads to profound immunosuppression with impaired humoral and cell-mediated immune responses [35]. This immunosuppression probably accounts for the observed in vivo balance between rejection and GVHD.

Diflo et al. [26] observed a short, sublethal GVHD approximately 4-6 weeks after fully allogeneic transplantation in immunosuppressed animals. Donor pretreatment with ALS completely eliminated GVHD but had no effect on graft survival in these immunosuppressed hosts. Gundlach et al. [39] found that mesenteric lymphadenectomy, a method that has been shown to eliminate GVHD [102], does not influence the course of acute graft rejection in nonimmunosuppressed recipients. CyA was not effective in preventing chronic rejection following mesen- 
teric lymphadenectomy, whereas the same dosage of $\mathrm{CyA}$ fully prevented rejection of normal small bowel grafts. They suggested that the absence of an immunosuppressive effect caused by a GVH reaction had led to chronic rejection in this model.

We showed that irradiation of the donor with $10 \mathrm{~Gy}$ 1 day before fully allogeneic SBT in the WAG-to-BN rat model completely eliminated GVHD and significantly shortened survival times [114]. Moreover, CyA treatment of the recipient was unable to completely override this effect [115]. Pretreatment of the donor with ALS also eliminated clinical GVHD and led to significantly accelerated rejection [12]. When our recipients of a graft pretreated with ALS received immunosuppressive treatment with CyA, no adverse effect on graft survival was seen any more, whereas clinical GVHD remained suppressed. This important finding is in accordance with earlier findings from our laboratory [115]. The usefulness of manipulating this balance for future clinical SBT remains to be established since it is as yet unclear whether this balance theory is a rat strain-dependent phenomenon and whether GVHD will even be a clinical problem.

Prevention of GVHD in SBT often implies reducing the immunogenicity of the graft also. In attempts to control both rejection and GVHD, reducing the immunocenicity and, consequently, diminishing the number of leukocytes in the graft, has been carried out. Moreover, in the recipient, the immunosuppression used to prevent rejection also suppresses GVHD, although in semiallogeneic rat models $\mathrm{CyA}$ appears to be less effective in preventing GVHD than in preventing rejection. FK 506 may even enhance GVHD $[10,94]$.

Several donor pretreatment modalities have been shown to abrogate or diminish clinical GVHD following experimental SBT. Total body irradiation of the donor prior to transplantation completely eliminates GVHD $[23,67,90]$, as does pretreatment of the donor with ALS [130], mesenteric lymphadenectomy [23], and reducing the length of the graft [55].

High levels of the cytokine tumor necrosis factor alpha (TNF $\alpha$ ) are measured in rats with lethal GVHD after SBT in a P-to-F1 GVHD model [103]. Blocking of TNF $\alpha$ activity reduces the mortality of GVHD after experimental bone marrow transplantation and prevents skin and gut lesions of GVHD [101]. This suggests that anti-TNF $\alpha$ antibody therapy could be helpful in reducing the severity or lethality of GVHD. Other cytokines may also be involved in the pathogenesis of GVHD [91] and are important in graft rejection as well. Anticytokine therapy might, therefore, prove to be valuable in concert with other immunosuppressive modalities.

\section{Graft physiology}

The small bowel exhibits nutritional, motor, hormonal, and immunological functions. After transplantation, changes in these functions may be expected for several reasons including the ischemia, lymphatic disruption, and denervation caused by the transplant procedure, the immunological processes arising after allogeneic transplantation, and the immunosuppressive drugs given. The small bowel transplant must be able to overcome the symptoms of short bowel syndrome. In the adult recipient, long-term prevention of malnutrition, and in children, normal growth and development followed by long-term prevention of malnutrition, are prerequisites for successful clinical SBT.

\section{Nutritional function}

A sensitive functional test is whether a small bowel transplant recipient is able to grow and develop normally. Several studies have shown that rats are able to gain weight normally after allogeneic total SBT $[11,125]$. However, rats grafted with a segmental small bowel transplant may develop impaired nutritional parameters [125] or grow suboptimally [11, 96], although Kirsch et al. [59] have shown that there were no significant differences in growth between sham-operated rats, animals with $50 \%$ of their bowel (jejunum) intact, and animals transplanted orthotopically with $50 \%$ of their total bowel length of jejunum 150 days post-transplantation. Moreover, just like the native gut after bowel resection, the transplanted intestine is capable of adaptation (i.e., increased bowel diameter and increased villus height) [59]. In dogs, conflicting data have been reported. Long-term surviving, allografted dogs maintain their preoperative body weight but have only slightly better nutritional parameters than dogs with short gut syndrome [27]. Weight after transplantation of a 100$\mathrm{cm}$-long segmental ileal allograft was maintained at $88 \%$ of its preoperative weight [18]. Autotransplanted dogs did not attain their preoperative weight until 1 year after transplantation [107]. Moreover, it has been reported that substantial nutritional disturbances/can be expected from lymphatic and neural division alone [3]. Recently, it was shown that autotransplanted adult dogs regain their preoperative weight within 1 year after transplantation. One year post-transplantation, these animals still had elevated stool moisture content and developed steatorrhea and impaired D-xylose absorption [143]. However, MHCmatched, CyA-treated recipients of a $45-$ to $65-\mathrm{cm}$-long allograft of terminal ileum did not differ in growth or fecal fat content from sham-operated controls, indicating adequate nutritional function (Meijssen et al., submitted). In young pigs, total small bowel allografts are able to adequately sustain the recipients' growth at a rate comparable to that of normal controls [34]. Porcine segmental jejunal allografts comprising approximately $25 \%$ of the 
small bowel length are incapable of doing the same; by 180 days after transplantation animals had increased their weight by only $40 \%$ [56], as compared to more than $100 \%$ in 4 weeks in Grants' animals. From these studies it seems that, from a nutritional point of view, allotransplantation will be possible. Taking into account its limitations (living related donation, abdominal size), as much bowel length as possible should be transplanted. More studies are needed to determine whether long-term functioning of SBT is feasible in both juvenile and adult recipients as opposed to long-term total parenteral nutrition, and how compromised functions may be restored.

\section{Immune function}

The gut mocosa has an important barrier function with regard to luminal food antigens and pathogens [5]. It is constantly challenged by microbial and food antigens, and its responses to these stimuli must be appropriate; infections must be limited but, at the same time, the integrity of the vulnerable mucosa must not be compromised. Intestinal immunity was first observed when protective "coproantibodies" were found in stools of orally immunized rabbits. However, the vulnerable gut mucosa should also be protected against potentially harmful reactions to harmless antigens. Indeed, suppressive mechanisms after immunization with harmless antigens have been observed and are called "oral tolerance" [146]. How the suppressive and inductive immunoregulatory mechanisms are established in the intestine is still not clear. The secretory immunoglobulin $(\mathrm{Ig})$ system is the major effector mechanism of mucosal immunity. Approximately $70 \%-80 \%$ of all Ig is produced by $B$ lymphocytes in the mucosa of the small and large bowel. This secretory $\operatorname{Ig}$, which is mainly $\operatorname{IgA}$, is transported to the gut lumen through the epithelial cells of Lieberkühn's crypts.

Numerous T lymphocytes are localized in the gut epithelium. In contrast to the lamina propria T lymphocytes, these intraepithelial lymphocytes (IEL) are in direct line with macromolecules in transit across the epithelium [29]. Their function is still obscure, but they are thought to play a role in cytotoxic as well as suppressive immune reactions. Apart from these solitary cells, the gut also contains organized solitary lymph nodes and lymph node aggregates: Peyer's patches. These are probably the major site of antigen presentation and commitment to sIgA synthesis in the mucosal-associated lymphoid tissue. Sensitized and committed cells migrate via the mesenteric lymph node and the bloodstream to distant gut. IgA-producing cells may also migrate to other mucosal surfaces that are part of the mucosal-associated lymphoid tissue, such as the lung, mammary glands, salivary glands, and lacrimal glands [146].

The immune function of bowel transplants is largely unknown. Both in humans [50] and in experimental ani- mals [66] it was found that graft lymphocytes are replaced by cells of recipient origin without the occurrence of rejection. Xia and Kirkman [154] found no differences in graft total slgA production after syngeneic and semiallogeneic SBT in rats. Immunosuppression with CyA had no effect on the total sIgA production. However, allografted animals treated with CyA failed to produce significant amounts of specific anticholera toxin $\operatorname{sg} \mathrm{A}$ when challenged with choleratoxin at the time of transplantation. The specific immune response to cholera toxin remained completely suppressed as long as the animals received CyA [156]. When allografted animals were boosted with choleratoxin 7 days post-transplantation, after having been primed 1 week before transplantation, normal sIgA levels were measured [155]. The presence of (part of) the recipient's colon could be important since it also contributes to gut mucosal immunology. The effect of different immunosuppressive agents on graft immune function needs to be investigated.

\section{Motor function}

The motility of the normal, intact upper gut has been well characterized. The stomach and small intestine display distinct patterns of motility during fasting and feeding. During the fasting or interdigestive period, the upper gut shows a spontaneous and recurrent cyclic pattern of motility, called the migrating motor complex (MMC) or interdigestive myoelectric complex. Feeding interrupts this MMC and induces a less well-defined, noncyclic pattern of intermittent, low-amplitude contractions that persist for a variable period of time, depending on the type and amount of nutrient. These motor patterns are physiologically important. During fasting, the MMC sweeps nondigestable intraluminal debris from the stomach and small intestine ("intestinal housekeeping"). The change in motor pattern caused by feeding is believed to maximize the mixing of food and to facilitate its absorption.

Schiller et al. [119] noted alterations in the mptility of jejunal segments transplanted in the neck of recipient dogs. In Lew rats that had received a ségmental syngeneic SBT, basal electrical rhythm of the graft was not observed for approximately 2 days after transplantation and did not attain the level of normal rats for at least 3 weeks. MMC was not observed in the transplanted segment until postoperative day 11 and became constant starting on postoperative day 16 [148]. In a dog model of small bowel autotransplantation, in which all extrinsic neural and lymphatic connections to the jejunoileum were transected, the MMC was present, although the coordination between the innervated duodenum and the denervated jejunoileum, present in the normal gut, was lacking [118]. The presence of MMC is of importance since its intestinal housekeeping function is thought to be essential in preventing bacterial overgrowth, a situation also encoun- 
tered after SBT (see below). Feeding or infusing the putative postprandial peptide hormones cholecystokinin or pentagastrin induced a normal "fed" pattern of contractions [118]. This implies that the intrinsic nerves of gut are capable of generating these motor patterns without input from the central nervous system.

\section{Hormonal function}

A number of hormones are produced by cells scattered diffusely throughout the length of the gut. The physiological role of these peptides is still being evaluated. Intraluminal levels of vasoactive intestinal peptide, somatostatin, and substance $P$ are stable from 4 days after syngeneic SBT to 1 year post-transplantation. During rejection, however, lowered levels of these hormones have been found [142]. LaRosa et al. [65] reported that SBT does not alter the baseline levels of serotonin and substance $P$ or their response to stimuli.

\section{Monitoring of graft rejection}

Unlike renal, hepatic, and pancreatic grafts, intestinal grafts have, as yet, no specific, distinguishing serum markers to diagnose rejection. Histology remains the gold standard for the diagnosis of rejection [86], although this method has several short-comings. Full thickness biopsies from the graft have to be taken from cutaneous stomas to reliably recognize rejection [89], which involves the risk of graft perforation. Multiple biopsies are necessary because rejection shows a patchy character and may be easily missed $[25,84,120]$. In view of these limitations, several small bowel function tests have been studied to determine their usefulness as markers for rejection. Function tests of the graft that need biopsy material from the graft, such as the determination of brush border enzyme activity [87, 127], have the same disadvantage of being dependent upon the presence of an enterostoma. Moreover, they do not detect rejection at an earlier stage than does histology. Functional tests, functional absorption tests, and putative serum markers of rejection must be at least as sensitive and as specific as histology in order to be considered an alternative to histology.

In order to be absorbed, the disaccharide maltose must be split into glucose by the brush border enzyme maltase. This glucose is subsequently absorbed and raises the blood glucose level. In this way, the maltose absorption test can be performed as a glucose tolerance test. Billiar et al. [4] studied this test in rats and found that a reduction in maltose absorption preceded histological changes by $1-$ 2 days. They concluded that this test is a reliable, reproducible, and sensitive method for monitoring rejection.

Intestinal absorption of water, sodium, glucose, alanine, and lauric acid have also been proposed as early serum markers. These substances require active transport by the mucosa, and significant decreases in their absorption were found when the first changes in histology were present [25].

Intestinal permeability to ${ }^{51} \mathrm{Cr}$-EDTA is increased during rejection. In rats, a twofold increase was measured at the time minimal histological signs of rejection were present [37]. Assessment of urinary ${ }^{51} \mathrm{Cr}-\mathrm{EDTA}$ as a measure of intestinal permeability has already proved its usefulness, permitting early detection and treatment of an acute rejection episode after clinical small bowel-liver transplantation [36].

Monocyte-macrophage procoagulant activity is a measure of immune activation of mononuclear cells. Measured in peripheral blood mononuclear cells, elevated levels were observed before histological changes of allograft rejection and remained high throughout the course of rejection. This test appears to be an accurate serum marker for the detection of rejection $[54,132]$.

The lysosomal acid hydrolase $\mathrm{N}$-acetyl hexosaminidase (NAH) is elevated in serum in association with intestinal ischemia. A study performed in rats suggested that determination of serum NAH is a simple and rapid test that can prove useful as a serum marker for small bowel allograft rejection [77]. In contrast to this report, Meijssen et al. [85] found in a dog model that a significant rise in NAH occurred after histological changes related to acute rejection were visible.

Transepithelial potential difference has been studied to determine its value as a diagnostic tool for the early detection of rejection. Madara and Kirkman [76], using an in vitro method, found that a decreased spontaneous transepithelial potential difference, which is an index of baseline active transport resulting from electrogenic sodium absorption and chloride secretion, correlated with histological signs of rejection. Sodium-coupled glucose absorption, which is an index of villus function, and theophylline-stimulated chloride secretion, which mainly measures crypt cell function, decreased when structural changes indicative of rejection became apparent. Lee et al. [71] found that changes in basal transepithefial potential difference parallelled, and often preceded, histological changes of rejection. Because of the invasive nature of their method, they did not consider it a practical clinical tool. In a model of canine small bowel autotransplantation, Meijssen et al. [86] developed a noninvasive method using a double balloon catheter that was inserted in an enterostomy and isolated a loop of bowel in which electrophysiological measurements could be performed. It was shown that in vivo electrophysiological parameters provide a useful tool in the assessment of small bowel autotransplants. A reduction in transepithelial potential difference preceded degenerative mucosal changes in the graft. It was subsequently found that following allotransplantation, electrophysiological parameters correlate with histological alterations of acute rejection, thus dem- 
onstrating that serial monitoring of transepithelial potential differences is a noninvasive method for detecting small bowel allograft rejection that circumvents the disadvantages of histological monitoring [84].

\section{Preservation}

At present, no consensus exists about the method of choice or preservation solution for a small bowel graft, nor is it known what maximal ischemia time is tolerable. Euro-Collins solution may be the best preservation fluid for the canine small bowel, as compared to University of Wisconsin (UW) solution or Ringer's lactate [40], but in rats $U W$ solution seems to be the most effective preservation solution [129]. The mucosa of the small bowel is very susceptible to ischemia and reperfusion injury [99]. Vascular and luminal perfusion of the graft alone without cold ischemia leads to mucosal injury in rats that is completely healed $24 \mathrm{~h}$ after transplantation. After $5 \mathrm{~h}$ of cold ischemia at $4{ }^{\circ} \mathrm{C}$ using UW or Sacks' solution, the mucosa of the graft was significantly injured, but $24 \mathrm{~h}$ after transplantation there was complete healing of the mucosa. However, $18 \mathrm{~h}$ of cold ischemia led to severe injury that was still present $24 \mathrm{~h}$ after transplantation [98].

The pathophysiology of reperfusion injury involves the formation of oxygen-derived free radicals [99]. It has been shown that the addition of free radical scavengers, such as superoxide dismutase, to the preservation fluid may be beneficial to the small bowel graft $[74,139]$.

In a recent series of successful clinical SBT, a simple preservation method proved to be appropriate: simple core cooling of the graft with UW solution without extensive flushing of the capillary bed, followed by immersion in an ice bath. Even intraluminal washing was omitted, leaving the succes entericus in the graft, with no consequent infection from this practive [145]. Using UW solution, satisfactory preservation for up to $16 \mathrm{~h}$ has been reported in humans [21].

\section{Small bowel transplantation in humans}

Before CyA became available, attempts at clinical SBT were invariably unsuccessful. Failures were due to technical complications, rejection, GVHD, and sepsis [57]. These discouraging results, and the availability of TPN, led to a diminished interest in SBT.

Several successful SBT have been reported since CyA was introduced. Deltz et al. [24] reported a case of successful SBT using a 60 -cm segment of jejunum and ileum harvested from the sister of the recipient. Although this graft was not rejected, the patient had severe diarrhea. The graft donor also developed chronic diarrhea. Nine attempts at SBT in seven children have resulted in one successful case in which the recipient is alive more than
3 years after grafting. In all of the other patients the grafts had to be removed because of necrosis or because rejection was uncontrollable [33]. The combined European experience in SBT was recently reported by Schroeder et al. [126]: from March 1987 until July 1990, 15 SBT were performed in 12 patients. Four grafts are presently functioning, with patients independent of TPN. Immunosuppression in these patients was with CyA and prednisone, usually supplemented with azathioprine and ALS. In one patient transient GVHD was encountered. Recently, a successful case of multiorgan transplantation including liver, pancreas, stomach, and small bowel was reported by Margreiter et al. [78]. Two minor rejection episodes of the bowel were encountered. Six months postoperatively all grafted organs functioned normally.

McAlister et al. [83] performed isolated SBT, as well as combined small bowel-liver transplantation and abdominal cluster transplantation; the isolated small bowel transplant had to be removed 15 days post-transplantation because of uncontrollable rejection. Two of three patients with small bowel-liver transplantation are alive on CyA therapy, whereas the other died from a nonimmunological cause. One of two patients given an abdominal cluster transplant is well 7 months post-operatively, whereas the other died of a lymphoma. Todo et al. [145] reported on eight isolated SBT and eight small bowel-liver transplantations using FK 506 as the main immunosuppressant. Seven of the eight isolated small bowel transplants are functioning, and all patients who have their graft for more than 2 months are free of TPN. Of the eight small bowelliver graft recipients, one died of sepsis and GVHD 23 days post-transplantation. The other seven have grafts functioning from 7 to 23 months post-transplantation and are free of TPN.

In all clinical cases, intestinal continuity was restored in stages. During the first operation, the proximal and distal ends, or the distal end of the graft only, were brought out as enterostomies. This allowed for macroscopic inspection and graft biopsy in order to monitor graft rejection. Moreover, early alimentation of the graft or decpmpression in the case of ileus are possible. In a second operation some weeks later, intestinal continuity was restored, after which oral feedings could be instituted [24, 36, 145]. It should be noted, however, that pediatric patients had an aversion to food and preferred tube feedings.

Although in most of the cases reported the postoperative course was stormy, these successful cases suggest that SBT has become a clinical reality.

\section{Future prospects}

The reasons why the small bowel graft is particularly vulnerable to rejection are now being delineated. The high rate of sepsis after SBT $[37,126]$ has several causes. Immunosupression given to the recipient compromises the 
immunological barrier function of the bowel wall. Ischemia and rejection increase the permeability of the graft by compromising the physical barrier. This has been shown to lead to bacterial translocation to the host $[7,37]$. Leakage of toxins also occurs in this phase. This may be aggravated by the bacterial overgrowth in the graft encountered after SBT [7, 143].

Measures that maintain the gut barrier function after SBT will improve its outcome. Better immunosuppressive drugs, like RAPA, may have a higher therapeutic index than $\mathrm{CyA}$, although some believe that $\mathrm{CyA}$, as the mainstay of immunosuppressive therapy, will provide satisfactory immunosuppression $[78,126]$.

Several authors suggest that there may be an advantage to combined small bowel-liver transplantation, and this has been supported by recently performed successful clinical small bowel-liver transplantation [36]. In rats, SBT performed 17 days after orthotopic liver transplantation led to long-term survival of the small bowel graft without any immunosuppression, whereas isolated small bowel grafts were rejected in 6-9 days [117]. Similar results were reported by Zhong et al. [160]. In a series of clinical small bowel and small bowel-liver transplantations, however, the incidence of graft rejection in the first 2 months after isolated SBT was lower than after combined small bowel-liver transplantation. The greater ease and safety of isolated SBT in this series indicates that combined small bowel-liver grafting should only be reserved for patients with coexisting liver failure [145]

Early institution of feeding of the graft helps to prevent disuse atrophy $[72,109]$, and antibiotics reduce the bacterial load of the gut. Other options that one may wish to experiment with include the administration of hormones trophic to the gut, such as epidermal growth factor and prostaglandin $\mathrm{E}_{2}$, or the use of nutrients that are essential to the gut. One such nutrient that, in our opinion, deserves special attention is the amino acid L-glutamine. Several studies have demonstrated that glutamine is the principal fuel for enterocytes $[134,152]$. There is only limited evidence that glutamine is essential for maintenance of normal intestinal function [134]. However, the stress of a major operative procedure, combined with general anesthesia, is followed by a decrease in circulating and muscle glutamine concentrations [133]. During injury or stress, glutamine may be a necessary dietary component to maintain gut structure and function. This is possibly due to the fact that glutamine is essential for nucleic acid biosynthesis and might be especially important during critical illness when the mucosal barrier becomes susceptible to breakdown [134]. It has been shown, for instance, that glutamine consumption by the intestinal tract is increased by $75 \%$ after laparotomy [134]. It has also been shown that glutamine reduces bacterial translocation from the gut to the mesenteric lymph nodes following abdominal irradiation [135]. Moreover, glutamine supplementation of standard TPN solutions decreases the villous atrophy associated with long-term i.v. feeding [95], and bacterial translocation following TPN administration is attenuated when glutamine is added to the mixture. This diminished translocation was associated with a normalization of $\operatorname{sIg} \mathrm{A}$ levels and a decrease in bacterial adherence to enterocytes, suggesting that adding glutamine to the TPN solution enhances gut immune function $[2,13]$. Preliminary results also indicate that glutamine is able to prevent the mucosal atrophy seen after heterotopic SBT [128]. Taken together, these findings indicate that glutamine could have important applications after SBT that are worth investigating.

Early detection of rejection is of vital importance in preserving barrier function and may benefit long-term graft function since it could delay and/or reduce fibrosis and chronic rejection. Several serum and urinary markers are now available which, in conjunction with histology, allow early recognition and treatment of rejection, and new markers are still being sought. For example, the enzyme diamino-oxidase is a potentially interesting marker for both rejection and long-term graft function [112]. This enzyme, which is involved in the regulation of polyamine metabolism and probably also the regulation of mucosal growth, is produced mainly by mature enterocytes in the villus tip [111]. It may have elevated levels in serum during acute ischemic injury of the small bowel mucosa [153] and, hence, may be useful in detecting acute rejection. Normally, after i.v. heparin administration, a rapid increase in plasma diamino-oxidase is seen $[60,75]$. These postheparin plasma diamino-oxidase levels are lowered in small bowel mucosal damage [20] and could prove to be a marker for graft function, something which deserves further study.

Denervation, an inevitable consequence of SBT, causes hypersecretion from the crypts and diarrhea in the early stages after transplantation $[86,150]$. It is thought that long-term impaired motility as a result of denervation, although not hindering the passage of food, is associated with bacterial overgrowth. Increased chloride secretion [86, 150], steatorrhea $[107,122,143]$, and increased fecal water content [143] are all thought to be long-term consequences of extrinsic denervation of the graft.

Because these obstacles have now been traced and either removed or resolved, and because the first successful clinical cases are being reported, there is reason to be optimistic about the future of clinical SBT. 


\section{References}

1. Aeder MI, Payne WD, Jeng LBB, Sutherland DER, Najarian IS (1984) Use of enteral cyclosporine for small intestinal allotransplantation in dogs. Surg Forum 35: 387-390

2. Alverdy JA, A oys E, Weiss-Carrington P, Burke DA (1992) The effect of glutamine enriched TPN on gut immune cellularity. J Surg Res 52: 34-38

3. Ballinger WF, Christy MG, Ashby WB (1962) Autotransplantation of the small intestine: the effect of denervation. Surgery 52: 151-164

4. Billiar TR, Garberoglio C, Schraut WH (1984) Maltose absorption as an indicator of intestinal allograft rejection. J Surg Res 37: 75-82

5. Brandtzaeg P, Halstensen TS, Kett K, Krajci P, Kvale D, Rognum TO, Scott H, Sollid LM (1989) Immunobiology and immunopathology of human gut mucosa: humoral immunity and intraepithelial lymphocytes. Gastroenterology 97: 1562-1584

6. Brousse N, Canioni D, Rambaud C, Jarry A, Guy-Grand D, Goulet O, Revillon Y, Ricour C, Cerf-Bensussan N (1990) Intestinal transplantation in children: contribution of immunohistochemistry. Transplant Proc 22: 2495 2496

7. Browne BJ, Johnson CP, Edmiston CE, Hlava MA, Moore GH, Roza AM, Telford GL, Adams MB (1992) Small bowel transplantation promotes bacterial overgrowth and translocation. J Surg Res 51: 512-517

8. Bruin RWF de, Heineman E, Meijssen MAC, Jeekel J, Marquet RL (1990) The effect of pretransplant donor-specific blood transfusions on various segments of small bowel grafts. Transplantation 50: 928-930

9. Bruin RWF de, Saat RE, Heineman E, Jeekel J, Marquet RL (1990) The effect of cyclosporine A in small bowel transplantation in rats is dependent on the rat strain combination used. Transplant Proc 22: 2472-2473

10. Bruin RWF de, HogenEsch H, Heineman E, Jeekel J, Marquet RL (1991) Fulminant graft-versus-host disease after FK 506 treatment in fully allogeneic small bowel transplantation. Transplant Proc 23: 3257-3259

11. Bruin RWF de, Heineman E, Jeekel J, Meijssen MAC, Lindemans J, Bonthius F, Marquet RL (1992) Functional aspects of small bowel transplantation in rats. Scand J Gastroent 27: $483-488$
12. Bruin RWF de, Saat RE, Heineman E, Jeekel J, Marquet RL (1993) Effects of donor pretreatment with antilymphocyte serum and cyclosporin on rejection and graft-versus-host disease after small bowel transplantation in immunosuppressed and non-immunosuppressed rats. Transpl Int 6:22-25

13. Burke DJ, Alverdy JC, Aoys E, Moss GS (1989) Glutamine supplemented total parenteral nutrition improves gut immune function. Arch Surg 124: 1396-1399

14. Chang JY, Sehgal SN, Bansbach CC (1991) FK 506 and rapamycin: novel pharmacological probes of the immune response. Trends Pharmacol Sci 12: $218-223$

15. Chen H, Wu J, Xu D, Aboujaoude M, Strepkowski S, Kahan B, Daloze P (1992) The effect of rapamycin on orthotopic small bowel transplantation in the rat. Transplant Proc 24: 11571158

16. Cohen Z, Alasdair B, Mac Gregor B, Moore KTH, Falk RE, Langer B, Cullen JB (1976) Canine small bowel transplantation, a study of the immunological responses. Arch Surg 111: 248-253

17. Cohen Z, Nordgren SR, MacKenzie RD, Lossing AG, Stiller CR, Langer B (1983) Pharmacokinetics of cyclosporine in a canine intestinal transplantation model. Transplant Proc 15: 3013-3018

18. Collin J, Dennison AR, Watkins RM, Millard PR, Morris PJ (1987) Segmental small intestinal allografts. II. Inadequate function with cyclosporine immunosuppression: evidence of a protein losing enteropathy. Transplantation 44: 479-483

19. Crane PW, Ingham-Clark CL, Davies RL, Slavin G, Wood RFM, Lear PA (1990) Cyclosporine toxicity in the small intestine. Transplant Proc 22: 2432

20. D'Agostino L, Pignata S, Daniele B, D'Adamo G, Bianco AR (1991) Plasma postheparin diamine oxidase in patients with small intestinal lymphoma. Cancer 67:511-515

21. D'Allesandro AM, Kalayoglu M, Sollinger HW, Pirsch JD, Belzer FO (1992) Liver-intestinal transplantation: report of a case. Transplant Proc 24: $1228-1229$
22. Deltz E, Müller-Hermelink HK, Ulrichs K, Thiede A, Müller-Ruchholtz W (1981) Development of graft-versus-host reaction in various target organs after small intestine transplantation. Transplant Proc 13: 1215-1216

23. Deltz E, Ulrichs K, Schack T, Friedrichs B, Müller-Ruch holtz W, MüllerHermelink HK, Thiede A (1986) Graft-versus-host reaction in small bowel transplantation and possibilities for its circumvention. Am $\mathbf{J}$ Surg 151: 379-386

24. Deltz E, Schroeder P, Gebhardt H, Gundlach M, Timmermann W, Engemann R, Leimenstoll C, Hansman ML, Westphal E, Hamelmann H (1989) Successful clinical small bowel transplantation: report of a case. Clin Transplant 3: 89-91

25. Dennison AR, Collin J, Watkins RM, Millard PR, Morris PJ (1987) Segmental intestinal allografts in the dog. I. Morphological and functional indices of rejection. Transplantation 44: 474-478

26. Diflo T, Maki T, Balogh T, Monaco AP (1989) Graft-versus-host disease in fully allogeneic small bowel transplantation in the rat. Transplantation 47: 7-11

27. Diliz-Perez HS, McClure J, Bedetti C, Hong HQ, de Santibanes E, Shaw BW, Van Thiel D, Iwatsuki S, Starzl TE (1984) Successful small bowel transplantation in dogs with cyclosporine and prednisone. Transplantation 37: 126-129

28. English J, Evan A, Houghton DC, Bennett WM (1987) Cyclosporine induced acute renal dysfunction in the rat. Evidence of arteriolar vasoconstriction with preservation of tubular function. Transplantation 44: 135-141

29. Ernst PB, Befus AD, Bienenstock J (1985) Leukocytes in the intestinal epithelium: anyunusual immunological compartment. Immunol Today 6: 5055

30. Fecteau A, Tchervenkov J, Guttman FM, Rosenmann E (1992) Small bowel transplantation in the rat: the effect of donor specific transfusion 24 hours pretransplant and cyclosporine. Transplant Proc 24: 1166

31. Frantz FW, Terris DJ, Wyble CW, Halperin EC. Sanflippo F, Scroggs MW, Honoré G, Bollinger RR (1988) Allogeneic small bowel transplantation with cyclosporine and donor wholebody irradiation. Transplant Proc 20: 193-196 
32. Fukuzawa M, Santiago S, Nakata S, Shirakura R, Okada A (1991) Effect of donor-specific transfusion and FK 506 on small intestine allotransplantation. Transplant Proc 23: 3252 3254

33. Goulet O, Révillon Y, Jan D, Brousse N, De Potter S, Cerf-Bensussan N, Rambaud C, Buisson C, Pellerin D, Mougenot JF, Fischer A, Ricour C (1990) Small bowel transplantation in children. Transplant Proc 22: 24992500

34. Grant D, Duff J, Zhong R, Garcia B, Lipohar C, Keown P, Stiller C(1988) Successful intestinal transplantation in pigs treated with cyclosporine. Transplantation 45: 279-284

35. Grant D, Zhong R, Gunn H, Duff J, Garcia B, Keown P, Wijsman J, Stiller C (1989) Graft-versus-host disease associated with intestinal transplantation in the rat. Transplantation 48 545-549

36. Grant D, Wall W, Mimeault R, Zhong R, Ghent C, Garcia B, Stiller C, Duff J (1990) Successful small bowel/liver transplantation. Lancet 335: 181-184

37. Grant D, Hurlblut D, Zhong R, Wang P. Chen H, Garcia B, Behme R, Stiller C, Duff J (1991) Intestinal permeability and bacterial translocation following small bowel transplantation in the rat. Transplantation 52:221-224

38. Grant D, Zhong R, Hurlblut D, Garcia $\mathrm{B}$, Chen $\mathrm{H}$, Lamont $\mathrm{D}$, Wang $\mathrm{P}$, Stiller C, Duff J (1991) A comparison of heterotopic and orthotopic intestinal transplantation in rats. Transplantation 51: 948-954

39. Gundlach M, Schroeder P, Hansmann ML, Zwingers T, Deltz E (1989) Graft manipulation prior to small intestinal transplantation. Transplant Proc 21 2894-2895

40. Hamamoto I, Merhav H, Zhu Y, Suzuki M. Fujita S, Murase N, Todo S, Starzl TE (1992) Lipid peroxidation, brush border, and neutrophil enzyme activity after small bowel preservation: a comparison of preservation solutions. Transplant Proc 24: 1095

41. Hardy MA, Quint J, State D (1970) Effect of antilymphocyte serum and other immunosuppressive agents on canine jejunal allografts. Ann Surg $171: 51-60$

42. Hatazawa C, Yamaguchi M, Kato T, Koyama K (1992) Effect of FK 506 on small bowel transplantation in rats. Transplant Proc 24: 1177
43. Heineman E, Meijssen MAC, Bruin RWF de, Marquet RL, Molenaar JC (1991) Electrophysiological and histo logical monitoring of MHC-matched and mismatched canine intestinal allografts. J Pediatr Surg 26: 893-899

44. Hell K, Gundlach M, Schmidt P, Hansmann ML, Schroeder P, Deltz E (1990) Immunohistochemical analysis of immunocompetent cells involved in small bowel rejection in the rat. Transplant Proc 22: 2461-2462

45. Hoffmann AL, Makowka L, Banner B. Cai X. Cramer DV, Pascualone A. Todo S, Starzl TE (1990) The use of FK 506 for small intestine allotransplantation. Inhibition of acute rejection and prevention of fatal graft-versus-host disease. Transplantation 49: 483-490

46. Holmes JT, Klein MS, Winawer SJ, Fortner JG (1971) Morphological studies of rejection in canine jejunal allografts. Gastroenterology 61: 693-706

47. Hong J, Sumrani N, Delaney V, Davis

R, Tejani A, Friedman EA, Butt KMH (1991) The beneficial effect of cyclosporine preloading in renal transplants from HLA haploidentical living donors: Transplant Proc 23: 1003-1004

48. Howard JG, Woodruff MFA (1961) Effect of the graft-versus-host reaction on the immunological responsiveness of the mouse. Proc R Soc Lond [Biol] 154: 532-539

49. Hurlblut D, Garcia B, Ohene-Fianko D. Duff J, Grant D (1992) Immunohistochemical assessment of mucosal biopsies following human intestinal transplantation. Transplant Proc 24: 1195 1196

50. Iwaki Y, Starzl TE, Yagishashi A. Taniwaki S, Abu-Elmagd K, Tzakis A, Fung J, Todo S (1991) Replacement of donor lymphoid tissue in small-bowel transplants. Lancet 337: 818-819

51. Kahan BD, Wideman CA, Reid M, Gibbons S, Jarowenko M, Flechner S, Buren CT van (1984) The value of serial serum trough cyclosporine levels in human renal transplantation. Transplant Proc 16: 1205-1209

52. Kahan BD, Strepkowski SM, Chen H Baloze P (1991) Rapamycin suppresses host-versus-graft and graftversus-host responses after small bowel transplantation in histoincompatible rats (abstract). International Symposium on Small Bowel Transplantation, London, Ontario, Canada, p 136
53. Kaneko H, Fischman MA, Buckley TM, Schweizer RT (1991) A comparison of portal versus systemic venous drainage in the pig small bowel allograft recipient. Surgery 109: 663-670

54. Kim PCW, Levy GA, Craig M, Cullen J, Cohen Z (1990) Immune responses during small intestinal allograft rejection: correlation between procoagulant activity and histopathology. Transplant Proc 22: 2477-2479

55. Kimura K, Money SR, Jaffe BM (1987) The effects of size and site of origin of intestinal grafts on small bowel transplantation in the rat. Surgery 101: 618-622

56. Kimura K, LaRosa CA, Blank MA, Jaffe BM (1990) Successful segmental intestinal transplantation in enterectomized pigs. Ann Surg 211: 158-164

57. Kirkman RL (1984) Small bowel transplantation. Transplantation 37: $429-433$

58. Kirkman RL, Lear PA, Madara JL, Tilney NL (1984) Small intestine transplantation in the rat - immunology and function. Surgery 96: 280-286

59. Kirsch AJ, Kirsch SS, Kimura K, LaRosa CA, Jaffe BM (1991) The adaptive ability of the transplanted rat small bowel. Surgery 109: 779-787

60. Kobayashi Y, Kupelian J, Maudsley DV (1969) Release of diamine oxidase by heparin in the rat. Biochem Pharmacol 18: 1585-1591

61. Kocandrle V, Houttuin E, Prohaska JV (1966) Regeneration of the lymphatics after autotransplantation and homotransplantation of the entire small intestine. Surg Gynecol Obstet 122: $587-592$

62. Koltun WA, Madara JL, Smith RJ, Kirkman RL (1987) Metabolic aspects of small bowel transplantation in inbred rats. J Surg Res 42: 341-347

63. Kort WJ, Westbrock DL, MacDicken I, Lameijer LDF (1973) Orthotopic total small bowel transplantation in the rat. Eur Stro Res 5: 81-89

64. LaRosa CA, Kimura K. Dresner LS, Birnbaum E, Jaffe BM (1989) Cyclosporine absorption by transplanted rat small intestine. Transplantation 47: 736-738

65. LaRosa CA, Kimura K, Dresner L, Birnbaum E, Jaffe BM (1989) The effect of intestinal transplantation on in traluminal levels of serotonin and sub stance P. J Surg Res 46: 600-604

66. Lear PA, Cunningham AJ, Crane PW Wood RFM (1989) Lymphocyte migration patterns in small bowel transplants. Transplant Proc 21: 2881-2882 
67. Lee KKW, Schraut WH (1985) In vitro allograft irradiation prevents graft-versus-host disease in small bowel transplantation. J Surg Res 38: 364-372

68. Lee KKW, Schraut WH (1986) Small bowel transplantation in the rat: graft survival with heterotopic vs orthotopic position. In: Deltz E, Thiede A, Hamelmann $H$ (eds) Small bowel transplantation: experimental and clinical fundamentals. Springer, Berlin Heidelberg New York, pp 7-13

69. Lee KKW, Schraut WH (1986) Structure and function of orthotopic small bowel allografts in rats treated with cyclosporine. Am J Surg 151: 55-60

70. Lee KKW, Stangl MJ, Todo S, Langrehr JM, Starzl TE, Schraut WH (1990) Successful orthotopic small bowel transplantation with short term FK 506 immunosuppressive therapy. Transplant Proc 22: 78-79

71. Lee MD, Smith SD, Yunis EJ, Rowe MI (1989) In vivo transmural potential difference: an early monitor of rejection in small bowel transplantation J Pediatr Surg 24: 767-770

72. Levine GM, Deren JJ, Steiger E, Zinno R (1974) Role of oral intake in maintenance of gut mass and disaccharide activity. Gastroenterology 67 : 975-982

73. Lillehei RC, Goott B, Miller FA (1959) The physiological response of the small bowel of the dog to ischemia including prolonged in vitro preservation of the bowel with successful replacement and survival. Ann Surg 150 543-560

74. Lopez J, Naujokat P, Xavier R, Walters W, Toledo-Pereya LH (1991) Protective effect of nalmefene and naloxone on the ischemically damaged small bowel. Transplant Proc 23: 2448

75. Luk GD, Bayless TM, Baylin SB (1983) Plasma postheparin diamine oxidase, sensitive provocative test for quantitating length of acute intestinal injury in the rat. J Clin Invest 71:1308 1315

76. Madara JL, Kirkman RL(1985) Struc tural and functional evolution of jejunal allograft rejection in rats and the ameliorating effects of cyclosporine therapy. J Clin Invest 75: 502512

77. Maeda K, Schwartz MZ, Bamberger MH, Daniller A (1987) A possible serum marker for rejection after small intestine transplantation. Am J Surg 153: $68-74$
78. Margreiter R, Königsrainer A Schmid A, Koller J, Kornberger R, Oberhuber G, Furtwängler W (1992) Successful multivisceral transplantation. Transplant Proc 24: 1226-1227

79. Markus PM, Cai X, Selvaggi G, Cooper M. Harnaha J, Fung JJ, Starzl TE (1991) The effect of cyclosporine, rapamycin and FK 506 on the survival following allogeneic bone marrow transplantation. Transplant Proc 23: 3232-3233

80. Marquet RL, Heystek GY, Tinbergen WJ (1971) Specific inhibition of organ allograft rejection by donor blood. Transplant Proc 3: 708-710

81. Martinelli GP, Knight RK, Kaplan S, Racelis D, Dikman SH (1988) Small bowel transplantation in the rat: effect of pretransplant blood transfusions and cyclosporine on host survival. Transplantation 45: 1021-1026

82. Matusani H, Yagi M, Hashimoto T, lyobe T, Iwasa K, Tomita K, Kiriyama M, Shimizu K, Izumi R, Miyazaki I (1992) Suppression of the histologic changes in GVHD by FK 506 in rat small bowel transplantation. Transplant Proc 24: 1185-1186

83. McAlister V, Wall W, Ghent R, Zhong R, Duff J, Grant D (1992) Successful small intestine transplantation. Transplant Proc 24: 1236-1237

84. Meijssen MAC, Heineman E, Bruin RWF de, Kate FJW ten, Marquet RL, Molenaar JC (1991) Detection of canine intestinal allograft rejection by an in vivo electrophysiologic monitor ing. Transplantation 51:955-959

85. Meijssen MAC, Heineman E, Bruin RWF de, Marquet RL, Molenaar JC (1991) The value of $\mathrm{N}$-acetyl hexoxaminidase in detecting canine intestinal allograft rejection. Transplant Proc 23: 615-616

86. Meijssen MAC, Heineman E, Bruin RWF de, Veeze HJ, Bijman J, Jonge HR de, Kate FJW ten, Marquet RL, Molenaar JC (1991) Value of in vivo electrophysiological measurements to evaluate canine small bowel autotransplants. Gut 32: 1329-1335

87. Meijssen MAC, Heineman E, Bruin RWF de, Marquet RL, Molenaar JC (1992) Diminished functional capacity and compromised functional integrity in acute rejecting DLA-matched and mismatched canine small-bowel allografts. Transplant Proc 24: 1116-1117
88. Meijssen MAC, Heineman E, Bruin RWF de, Wolvekamp MCJ, Marquet RL, Molenaar JC (1992) Successful canine small bowel transplantation using major histocompatibility complex matched segmental ileal allografts. Transplant Proc 24: 1141-1142

89. Millard PR, Dennison AR, Hughes DA, Collin J, Morris P (1986) Morphology of intestinal allograft rejection and the inadequacy of mucosal biopsies in its recognition. $\mathrm{Br} \mathrm{J}$ Exp Pathol 67: 687-698

90. Monchik GJ, Russell PS (1971) Transplantation of small bowel in the rat: technical and immunological considerations. Surgery 70: 693-702

91. Mowat A McI (1989) Antibodies to IFN-y prevent immunologically mediated intestinal damage in murine graftversus-host reaction. Immunology 68 : $18-23$

92. Müller-Hermelink HK, Deltz E (1986) Graft-vs-host reaction after small bowel transplantation compared with graft-vs-host reaction after bone marrow transplantation. In: Deltz E, Thiede A, Hamelmann H (eds) Small bowel transplantation: experimental and clinical fundamentals. Springer, Berlin Heidelberg New York, $\mathrm{p} 109$

93. Murase N, Demetris AJ, Matzuzaki T, Yagihashi A, Todo S, Fung J, Starzl TE (1991) Long survival in rats after multivisceral versus isolated smallbowel allotransplantation under FK 506. Surgery 110: 87-98

94. Murase N, Demetris AJ, Woo J, Furuva $T$, Nalesnik $M$, Tanabe $M$, Todo S, Starzl TE (1991) Lymphocyte traffic and graft versus host disease after fully allogeneic small bowel transplantation. Transplant Proc 23: 3246-3247

95. O'Dwyer ST, Smith RJ, Hwang TL, Wilmore DW (1989) Maintenance of small bowel mucosa with glutamine enriched parenteral nutsition. J Parenter Entefal Nutr 13: 579-585

96. Oki K, Maeda K, Nakamura K (1989) Orthotopic small intestine transplantation in the rat: how long a small intestinal graft is necessary? Transplant Proc 21: 2909-2912

97. Opelz G, Terasaki PI (1976) Prolongation effect of blood transfusions on kidney graft survival. Transplantation 22: $380-383$

98. Park PO, Wallander J, Tufveson G, Haglund U (1991) Cold ischemic and reperfusion injury in a model of smal bowel transplantation in the rat. Eur Surg Res 23: 1-8 
99. Parks DA, Bulkley GB, Granger DN, Hamilton SR, McCord JM (1982) Ischemic injury in the cat small intestine: role of superoxide radicals. Gastroenterology 82: 9-13

100. Penn I (1991) The changing pattern of posttransplant malignancies. Transplant Proc 23: 1101-1103

101. Piguet PF, Grau GE, Allet B, Vassalli $P$ (1987) Tumor necrosis factor/cachectin is an effector of skin and gut lesions of the acute phase of graft-vs-host disease. J Exp Med 166: 1280-1289

102. Pirenne J, Lardinois F, D'Silva M, Fridman V, Boniver J, Mahieu P, Degiovanni G, Jaquet N (1990) Relevance of mesenteric lymph nodes to graft-versus-host disease following small bowel transplantation. Transplantation 50: 711-713

103. Pirenne J, Dunn DL (1991) Relevance of tumor necrosis factor alpha (TNF) to graft vs host disease (GVHD) after small bowel transplantation (SBTx) (abstract). International Symposium on Small Bowel Transplantation, London, Ontario, Canada, p 74

104. Preston FW, Macalalad F, Wachowski TJ, Randolph DA, A postol JV (1966) Survival of homografts of the intestine with and without immunosuppression. Surgery 60: 1203-1210

105. Pritchard TJ, Kirkman RL (1985) Small bowel transplantation. World $\mathbf{J}$ Surg 9: 860-867

106. Pritchard TJ, Koltun WA, Kirkman RL (1986) Technical aspects of small intestinal transplantation in young pigs. In: Tumbleson ME (ed) Swine in biomedical research, vol 1. Plenum Press, New York London, pp 391-398

107. Raju S, Fujiwara H, Grogan JB, Achord JL (1989) Long-term function of orthotopic small bowel autotransplants. J Surg Res 46: 142-146

108. Reznick RK, Craddock GN, Langer B, Gilas T, Cullen JB (1982) Structure and function of small bowel allografts in the dog: immunosuppression with cyclosporin A. Can J Surg 25: 51-55

109. Riecken EO, Stallmach A, Zeitz M, Schulzke JD, Menge H, Gregor M (1989) Growth and transformation of small intestinal mucosa-importance of connective tissue, gut associated lymphoid tissue and gastrointestinal regulatory peptides. Gut 30: 1630-1640

110. Rogerson ME, Marsden JT, Reid KE, Bewick M, Holt DW (1986) Cyclosporine blood concentrations in the management of renal transplant recipients. Transplantation 41: 276-278
111. Rokkas T, Vaja S, Taylor P, Murphy GM, Dowling RH (1990) Is the intestine the sole source of heparin-stimulated plasma diamine oxidase? Digestion 46: 439446

112. Rose SG, Thompson JS, Spanta AD, Eamonn MM, Quigley MD (1991) The effect of intestinal autotransplantation on serum diamine oxidase activity. J Surg Res 50: 223-227

113. Rotman N, Michot F, Hay JM, Fagniez PL (1986) Lymphatic regeneration following intestinal transplantation in the pig. In: Deltz E, Thiede A, Hamelmann H (eds) Small bowel transplantation: experimental and clinical fundamentals. Springer, Berlin Heidelberg New York, pp 34-36

114. Saat RE, Heineman E, Bruin RWF de, Marquet RL, Jeekel J (1989) Total orthotopic small bowel transplantation in rats. Attempts to ameliorate the graft-versus-host disease by irradiation and transfusions of the donor. Transplantation 47: 451-453

115. Saat RE, Bruin RWF de, Heineman E, Jeekel J, Marquet RL (1991) Total orthotopic allogeneic small bowel transplantation in rats: effect of allograft irradiation combined with cyclosporine therapy. Gut 32: 654-656

116. Santiago SF, Fukuzawa M, Azuma T, Okada A (1991) Effect of donor pretreatment with FK 506 upon small intestine allotransplantation. Transplant Proc 23: 3243-3245

117. Sarnacki S Cerf-Bensussan N, Revillon Y, Calise D, Goulet O, Ricour C, Brousse N (1992) Long-term small bowel graft survival induced by spontaneously tolerated liver allografts in inbred rat strains. Transplant Proc 24: 1210

118. Sarr MG, Duenes JA. Tanaka M (1989) A model of jejunoileal in vivo neural isolation of the entire jejunoileum: transplantation and the effects on intestinal motility. J Surg Res 47 : 266-272

119. Schiller WR, Suriyapa C, Mutchler JHW, Gohara SF, Anderson MC (1973) Motility changes associated with canine intestinal allografting. J Surg Res 15: 379-384

120. Schmid T, Oberhuber G, Körözsi G, Klima G, Margreiter R (1989) Histologic pattern of small bowel allograft rejection in the rat. Gastroenterology 96: 1529-1532

121. Schmid T, Körözi G, Oberhuber G, Klima G, Margreiter R (1990) Lymphatic regeneration after small bowel transplantation. Transplant Proc 22: 2446
122. Schraut WH (1988) Current status of small bowel transplantation. Gastroenterology 94: 525-538

123. Schraut WH, Abraham VS, Lee KKW (1985) Portal versus systemic venous drainage for small bowel allografts. Surgery 98: 579-585

124. Schraut WH, Lee KKW, Dawson PJ Hurst RD (1986) Graft-versus-host disease induced by small bowel allografts: clinical course and pathology. Transplantation 41:286-290

125. Schraut WH, Lee KKW, Sitrin M (1987) Recipient growth and nutritional status following transplantation of segmental small bowel allografts. J Surg Res 43: 1-9

126. Schroeder P, Goulet O, Lear PA (1990) Small bowel transplantation: European experience. Lancet 336: $110-111$

127. Schroeder P, Gundlach M, Quaroni A Hansmann ML, Schweizer E, Deltz E (1990) Follow-up of small bowel transplantation by monoclonal antibodies against brush border membranes. Transplant Proc 22: 2476

128. Schroeder P, Schweizer E, Blömer A Deltz E (1992) Glutamine prevents mucosal injury small bowel transplantation. Transplant Proc 24: 1104

129. Schweizer E, Gassel A, Deltz E, Schroeder P (1992) Morphologic and histologic alterations after small bowel transplantation, a comparison of different perfusion solutions. Transplant Proc 24: 1087

130. Shaffer D, Maki T, DeMichele J, Karlstad MD, Bistrian BR, Balogh K, Monaco AP (1988) Studies in smal bowel transplantation. Prevention of graft-versus-host disease with preservation of allograft function by donor pretreatment with antilymphocyte serum. Transplantation 45: 262-269

131. Shaffer D, Diflo T, Love GHA, Clowes T, Maki T, Monaco AP (1989) Metabolic effects of systemic versus portal drainage of orthotopic small bowel isografts. Transplant Proc 21: 2872-2874

132. Silverman R, Cohen Z, Levy G, Craig M, Cullen J, Langer B (1987) Immune responses in small intestinal transplantation in the rat: correlation of histopathology and monocyte procoagulant activity. Surgery 102: 395-401

133. Souba WW, Wilmore DW (1983) Postoperative alteration of arteriovenous exchange of amino acids across the gastrointestinal tract. Surgery 94: 342 350 
134. Souba WW, Herskowitz K, Salloum RM, Chen MK, Augsten TR (1990) Gut glutamine metabolism. J Parenter Enteral Nutr 14: 45S-50S

135. Souba WW, Klimberg SV, Hautamaki RD, Mendenhall WH, Bova FC, How ard RJ, Bland KI, Copeland EM (1990) Oral glutamine reduces bacterial translocation following abdominal radiation. J Surg Res 48: 1-5

136. Stangl MJ, Gräb C, Mebert H, Fischer T, Weib M, Hammer C (1991) FK 506 and RS 61443 for reversal of small bowel rejection (abstract). International Symposium on Small Bowel Transplantation, London, Ontario, Canada, p 37

137. Storb R (1989) Graft rejection and graft-versus-host disease in marrow transplantation. Transplant Proc 21: 2915-2918

138. Strepkowski SM, Chen H, Daloze P, Kahan BD (1991) Rapamycin, a potent immunosuppressive drug for vascularized heart, kidney, and small bowel transplantation in the rat. Transplantation 51: 22-26

139. Sun SC, Greenstein SM, Schechner RS, Sablay LB, Veith FJ, Tellis VA (1992) Improved small intestinal preservation with additional use of superoxide dismutase to University of Wisconsin solution. Transplant Proc 24: 1092

140. Tadeka Y, Okajima K, Iga C, Date K, Ryo T, Niki M, Asaka K, Tezuka K, Isozaki H (1991) Effect of FK 506 on the survival of small bowel allografts. Transplant Proc 23: 3251

141. Taylor RMR, Watson JW, Walker FC, Watson AJ (1966) Prolongation of survival of jejunal homografts in dogs treated with azathioprine (Imuran). Br J Surg 53: 134-138

142. Teitelbaum DH, O'Dorisio M, Qualman SJ, Sonnino RE, Dunaway DJ, Harmel RP (1989) Alteration in gastrointestinal peptide tissue levels in rejecting small bowel transplants. J Pediatr Surg 24: 629-633
143. Thompson JS, Rose SG, Spanta AD, Quigly EMM (1992) The long-term effect of jejunoileal autotransplantation on intestinal function. Surgery 111: 6268

144. Thomson AW (1990) FK 506 enters the clinic. Immunol Today 11:35-36

145. Todo S, Tzakis AG, Abu-Elmagd K, Reyes J, Nakamura K, Casavilla A, Selby R, Nour B, Wright H, Fung JJ, Demetris AJ, Thiel DH van, StarzI TE (1992) Intestinal transplantation in composite visceral grafts or alone. Ann Surg 216: 223-234

146. Tomasi TB (1983) Mechanisms of immune regulation at mucosal surfaces. Rev Infect Dis 5: 784-792

147. Utusonomiya H, Tanaka K, Uemoto $\mathrm{S}$, Kato $\mathrm{H}$, Nishizawa T, Yamamoto $\mathrm{E}$, Ozawa K (1992) Effect of FK 506 on orthotopic small bowel transplantation in rats. Transplant Proc 24: 1191

148. Vane DW, Grosfeld JL, Moore W, Abu-Dalu K, Hurwitz A (1989) lmpaired bowel motility following intestinal transplantation. J Surg Res 47: 288-291

149. Wallander J, Läckgren $G$, Tufveson $G$ (1989) T-lymphocytes are necessary for fatal graft vs host disease after small bowel transplantation. Transplant Proc 21: 2896-2897

150. Watson AJM, Lear PA, Montgomery A, Elliot E, Dacre J, Farthing JG, Wood RFM (1988) Water, electrolyte, glucose, and glycine absorption in rat small intestinal transplants. Gastroen terology 94: 863-869

151. Williamson RCN, Chir M (1978) Intestinal adaptation. Structural, functional and cytokinetic changes. $\mathrm{N}$ Engl $\mathbf{J}$ Med 298: 1393-1402

152. Windmueller HG (1982) Glutamine utilisation by the small intestine. Adv Enzymol Relat Areas Mol Biol 53: 201-237
153. Wollin A, Navert H, Bounous $G$ (1981) Effect of intestinal ischemia on diamine oxidase activity in rat intestinal tissue and blood. Gastroentero$\log$ 80: 349-355

154. Xia W, Kirkman RL (1990) Immune function in transplanted small intestine, total secretory IgA production and response against cholera toxin. Transplantation 49: 277-280

155. Xia W, Kirkman RL (1990) Immune function in transplanted small intestine. II.sIg A production in cholera toxin primed rats. Transplant Proc 22: 2481-2482

156. Xia W, Kirkman RL (1991) Inhibitory effect of cyclosporine on specific secretory IgA production against cholera toxin in small bowel transplantation. Transplant Proc 23: 682-683

157. Xiao F, Foster PF, Sankary HN, Templeton AC, Kociss K, Williams JW (1992) The role of ultraviolet B-irradiated leucocyte transfusions and cyclosporine in intestinal transplantation. Transplantation 54: 32-37

158. Yamataka T, Miyano T, Kobayashi H, Noguchi H (1991) Immunosup pressive therapy in combination with anti-ICAM-1 mAb and FK 506 on small bowel transplantation ( $a b$ stract). International Symposium on Small Bowel Transplantation, London, Ontario, Canada, p 81

159. Zhong R, Wang P, Chen H, Sutherland F. Duff J, Grant D (1990) Surgical techniques for or thotopic intestinal transplantation in the rat. Transplant Proc 22: 2443-2444

160. Zhong R, He G, Sakai Y, Chang-Li X, Garcia B, Wall W, Duff J, Stiller C, Grant D (1991) Combined small bowel and liver transplantation in the rat: possible role of the liver in preventing intestinal allograft rejection. Transplantation 52: 550-552 